\title{
Implications of Advertising for Mass Media, Economy and National Development
}

\author{
Charles Onochie Okonji
}

\begin{abstract}
In Nigeria, advertising significantly plays notable roles within the economy. Unlike some developed countries where media organisations can survive with a mere subscription from readership and viewership, the situation is quite worrisome in Nigeria, as no media organisation can sustain its existence without advert patronage. With over 51 media organisations that operate both online and offline and another 95 that operate only online, none can comfortably boast of continued existence without advert patronage. It, therefore, becomes imperative to research the need for advertising for media organisations in Nigeria.

Aside from this, many companies have gone under because of ineffective marketing strategies for their products. This situation has become an issue of concern because of the loss of jobs and low return on investment, among other adverse economic implications. Now, most companies have embraced advertising as an effective strategy to reach out to their target market. The positive impact of this approach seems to be enormous on companies' profitability and entire economic architecture.

Index Terms - Advertising, mass media, persuasion, and target audience.
\end{abstract}

\section{INTRODUCTION}

Advertising, for officials of the Federal Government of Nigeria, companies' executives, and media owners, is a high premium strategy because of its drive to promote products and services. Government officials and business executives appreciate advertising, which is not only a structured and composed non-personal message, but also usually persuasive and must be paid for, because of its effective strategy to promote their products and services (Arens 2008). For media owners, advertising serves as a good revenue generation source for them.

According to Stanton (1994), advertising consists of activities, which present to the target audience a non-personal, sponsor-identified, paid-for message about a product, service, or organisation. The American Marketing Association (AMA) emphasised that non-personal communication could be ideas, goods, and services. Dominick (2007) stated that the sponsors must be identified.

From these researchers' perspectives, advertising has some characteristics or features. These features are:

[A] Commercial Value: The commercial value of advertising indicates that it must be paid for, as against news stories that do not have cost implications on the sources. Therefore, advertising is a paid message or communication.

Charles Onochie Okonji, Department of Mass Communication, Anchor University, Ayobo, Lagos
Even though news stories are not paid for, media organisations can recoup their investment from the payment of advertising they have published or aired. For instance, any Coca Cola advertisement in newspapers, radio, or television is paid for. This becomes a source of revenue for the media organisation.

[B] Form Of Communication: Advertising is a type of communication, though it is not the totality of communication, as there are other forms of communication. Other subsets of communication include verbal, non-verbal, interpersonal, intrapersonal, group, cultural, international, and mass communications, among others. The peculiar nature of advertising is that it is structured to adopt both verbal and nonverbal elements to fill specific space and time formats.

[C] Identified Sponsor: An advert must identify its sponsor. Bovee (1992) explained the identification of the sponsors of advertising because somebody must pay for it. This forms the basic differences between advertising and public relations. Advertising must be openly sponsored or paid for, while public relations engage in activities like publicity.

[D] Mass Audience: The audience of advertising is heterogeneous and scattered in different locations. If it is within one country alone, it is national advertising, but the very moment it passes the shore of a country and enters another country or more, it becomes multinational advertising. Sandage (2001), cited in Svetlana Frolova (2014), added the segmentation of the audience.

[E] Mass media as channels: Advertising reaches its target audience through the mass media. The advertising media can be the radio, television, newspaper, and magazine, among others. Sandage et al (1989), cited in Svetlana Frolova (2014), classified the transmission media like print, electronic, and outdoor.

[F] Non-personal application: Advertising is a non-personal form of communication, as it is typically directed to a heterogynous audience rather than an individual. This implies that the audience can be consumers, who obviously must reside in different locations, as against a particular area and they may not be a close associate of the advertiser or the sponsor of the message. Advertising influences the audience to buy the products and services for their personal or industrial use.

[G] Persuasive approach: Advertising is intended to be persuasive, or better still, to win converts for the product, service, or idea. Though some advertisements, such as announcements, are not to persuade, advertising must contain an element of persuasiveness to win the target audience. Asemah (2012) stated that the essence of persuasion is to lure 
the audience into patronising the advertised goods, services, or ideas.

Having looked at its basic features, it is now imperative to point out the impact, or better still, the implications of advertising to the mass media, economy, and national development. For this research, adverting will be looked at under these categories: advertising as revenue generation source for media organisations; advertising as an element of the marketing mix; advertising as a booster to profitability and shareholders' returns on investment; and advertising as an enhancement for international trade and relations.

\section{ADVERTISING AS REVENUE GENERATION SOURCE FOR MEDIA ORGANISATIONS}

Revenue from advertising, according to Agbanu and Nwamuo (2009), remains a major source of media finances. Corporate organisations in Nigeria spend millions of naira annually on the advertising of their products and services.

Nigeria, one of the largest advertising markets in Africa, spent \$425 million in 2017 (Guttmann, 2019). Only South Africa and Morocco spent more on advertising than Nigeria with $\$ 2.7$ billion and $\$ 820$ million respectively.

In 2018 , the country spent $\$ 419$ million, while in 2019 , it spent about $\$ 450$ million on advertising. Between 2017 and 2019 , the country spent over $\$ 1.031$ billion (N371.18 billion) on advertising.

Most of the advertising spending, according to Nairametrics (2019), was on TV and Video, with $\$ 156$ million in 2018, $\$ 165$ million in 2019, and $\$ 177$ million in the first half of 2020. Outdoor or Out of Home $(\mathrm{OOH})$ advertising followed with $\$ 118$ million in 2018, \$125 million in 2019, and $\$ 131$ million in the first half of 2020. Internet recorded $\$ 73$ million in 2018, \$86 million in 2019 and $\$ 99$ million in 2020, while radio recorded $\$ 42$ million in 2018, $\$ 44$ million in 2019 and $\$ 47$ million in 2020. The newspaper recorded \$26 million in 2018, \$25 million in 2019, and \$24 million in 2020.

Nwabueze et al (2012) highlighted the importance of advert revenue in the survival of Nigeria's mass media as follows:

[A] Employment Of More Staff: Advert revenues have helped the media organisations to expand their operations in terms of employment more staff and acquisition of more equipment and other facilities. This is because of the greater the coverage, larger audience, and increased advert sponsors.

[B] Expansion And Increased Coverage: With increase revenue generation, media organisations have expanded their audience size and could reach them at a faster rate. An increase in income can help a media organisation to achieve more area of coverage, a larger audience, and greater chances of attracting bigger and richer advert sponsors. It can eventually lead to more profits, which can be used to continue to expand their area of coverage.

[C] Lower Cover Prices Of Newspapers And Magazines: Advert revenue has help the publishers of print media to subsidise the cover price of newspapers and magazines, thus making them easily available to the majority of people. With lower cover prices, the print media have extended their readership and increase profitability. Therefore, without advert revenue, most newspaper and magazine outlets in Nigeria would find it difficult to survive. This is because if these publications try to make a profit from cover price, the publications may be unaffordable to their Nigerian audience, thereby culminating in lower sales and lower profit to them.

[D] Promotion Of Independence: Many media organisations cannot perform their watchdog function effectively because of over-dependence on the government for sustenance. Advert revenue helps the media to guard their freedom. Common parlance stated that he who pays the piper dictates the tune. Private owned media can afford constructively criticize the government's policies and its short-comings, but a medium that relies on the government for subvention cannot dare it.

[E] Prompt Payment Of Salaries And Allowance: Media workers, as of today, are looked at as beggars. With advert revenues, media organisations can pay staff salaries. Advert revenue can increase the media's profit and guarantee prompt payment of salaries. This, in turn, can encourage the staff to offer their best to their employers.

[F] Stay Afloat In Business: Without advert revenue, many media organisations, especially privately owned ones, might not have remained in business today. Government-owned media could still exist because of the subvention from the government. Advert revenue has helped some of the privately-owned media tackle their operational cost, despite the ever-increasing prices of diesel and fuel, which they need to power their generators during a power outage.

\section{ADVERTISING AS AN ELEMENT OF THE MARKETING MIX FOR COMPANIES' PERFORMANCE}

Companies engage the marketing mix as a profound strategy to remain afloat. The marketing mix involves the use of different marketing instruments to achieve positive financial results. The elements within the 4Ps of Integrated Marketing Communication (IMC) include product, price, place, and promotion. Lasune et al (2011) added three other elements, which are pace, packaging, and positioning, to the mix. They analysed these elements of the marketing mix under the following perspectives:

[A] Advertising And Pace: Pace refers to the speed in marketing decisions and actions. It involves, among other things, the frequency of the launch of new products or brand variations. As new brands are launched, advertising would inform, educate, and persuade the customers to buy the product.

[B] Advertising And Packaging: Products are packaged for various reasons. Firstly, it is to protect them during transit. Secondly, it is to preserve the quality and quantity. Firms make efforts to develop and design attractive packages to attract the attention of the customers. Advertising explores this value to assure the target market of the product quality and create confidence in their minds to buy the product.

[C] Advertising And Place: Place refers to the physical location and the stores where the goods and services can be available. Production is not complete until the products have got to the hands of the consumers. Thus, firms make sure that the goods are available at a convenient place and at the right 
time when the buyers. To facilitate effective distribution and expansion of a product, a firm must engage advertising to inform the consumers where to get the product. Significantly, therefore, advertising enhances the effective distribution and market expansion of products and services.

[D] Advertising And Positioning: The essence of positioning is to create and maintain a distinct brand image in customers' minds. Through advertising, companies position the brand and influence the buying decision of the target audience.

[E] Advertising And Price: The price is the exchange value of the product. When a company produces a very high-quality product with additional features, its price will be high. The customers may not be willing to pay the high price if the product has good competitors. To be able to maintain its market share, the producer will explore advertising to win converts. The advertising will convince buyers regarding the superiority of the brand and its value for money. It can be done by associating the product with prestigious people, situations, or events. Also, when a firm offers a low price product, the advertising can stress the price advantage.

[F] Advertising And Product: A product is normally a set of physical elements, such as quality, shape, size, colour, and other features. In designing a product, the manufacturer will inform and educate the buyers on the various aspects of the product. However, this can effectively be communicated to them through advertising. Thus, advertising has played the role of information and education about the product.

[G] Advertising And Promotion: Promotion consists of advertising, publicity, personal selling, and sales promotion techniques. Businessmen, today, face a lot of competition. Every seller needs effective promotion strategies to survive and succeed in this competitive environment. Advertising puts the seller's claim to the target market and also counters the competitors' claims against the product. With effective advertising, sellers can face competition and develop a brand image with loyalty.

\section{ADVERTISING AS A BOOSTER TO PROFITABILITY AND SHAREHOLDERS' RETURNS ON INVESTMENT (ROI)}

Advertising has greatly influenced several organisations. They use it as a promotional strategy to sell products and services, promote causes, market political candidates, and deal with societal problems (Belch and Belch (2003).

Sector analysis of advertising spending in Nigeria revealed that the telecommunications sector dominated with \$43 million (N15.4 billion) in 2019, while personal paid advertising followed with $\$ 19.4$ million (N7 billion). On the highest spenders analysis, MTN led with N7 billion, while Nigerian Breweries ranked sixth with a \$6.9 million (N2.5 billion) advertising expenditures (Nairametrics 2019).

The brewery industry spent about N41.6 billion in 2018 compared to N36.4 billion in 2017. Between and third quarter of 2019, the sector spent about N39 billion. BInbev's acquisition of International Brewery resulted in the company's huge spending on advertising. The company spent N9 billion in 2019, as against N7.86 billion in 2018. Nigerian Breweries spent N22.4 billion in 2017, N23.7 billion in 2018, and N21.3 billion in 2019

Apart from the Brewery sector, the banking sector also recorded significant spending on advertising with about N31.9 billion in 2019. The sector spent N52.9 billion in 2018 and about N50.4 billion in 2017. Access Bank's merger with Diamond Bank pushed up the banking sector's spending on advertising, with over N5.9 billion in the first 9 months of 2019. It spent N4.8 billion in 2018 and N6 billion in 2017. However, Zenith Bank remains the highest spender with over N9 billion spent in 2018. In the first nine months of 2019, the bank spent about N5.1 billion. Between 2017 and 2019, the banking sector spent about N135.3 billion (Nairametrics 2019).

Effectively and efficiently, advertising communicates products and services to their target audiences. Towards this, it plays these roles:

[A] Creation Of Good Public Image: In a crisis, advertising helps to restore a good reputation to organisations. It enables a firm to communicate its achievements to satisfy the customers' needs, which can increase the goodwill and reputation of the firm. It can equally help to fight against both local and foreign competition in the market.

[B] Education Of People: For new products, government policies, and disease pandemic, advertising educates the people. With the current COVID-19 pandemic, Nigeria and other countries used advertising to educate the people on how to keep safe - maintaining of social distancing and sanitizing of their hands, among others. It has helped people to adopt new ways of life and give up old habits. It has contributed a lot to curtail the spread of the Corona Virus.

[C] Introduction Of A New Product: Advertising helps firms to introduce new products to the market. Not only products but companies can also introduce themselves to the public through advertising. An emerging company may not make an impact on prospective customers without advertising. It is only through advertising that the company came to make a quick and reasonable impression in the market.

[D] Mass production: Advertising facilitates large-scale production, as it encourages mass production of goods. It enables firms to sell on a large-scale, thus reduces the cost of production per unit.

[E] Promotion Of Sales: Through information and persuasion, advertising promotes the sale of goods and services. A good advertising campaign helps to win new customers both in the national and international markets.

[F] Stimulation Of Research: Companies try to differentiate their products from other substitutes. Advertising craves for Unique Selling Proposition (USP) and this compels firms to engage more in research to improve their products with new uses. Engagement in research and development activities helps companies not only to remain the market but also to have a greater share of it.

\section{ADVERTISING AS AN ENHANCEMENT OF INTERNATIONAL TRADE AND RELATIONS}

Advertising is an integral part of everyday life. Over the years, marketers have adopted various methods to advertise 
their products and services, which have helped their survival. Multinational advertising, or better still international advertising, has helped companies and organisations to carve a niche beyond their national boundaries.

[A] The Building of Brand Loyalty: Multinational advertising helps to build a brand. By creating or reinforcing a brand's personality, multinational advertising enhances brand value or equity which in turn can be leveraged through brand extension. Brand personality also helps brands to gain market share.

[B] Global Marketing Of Products And Services: Advertising has encouraged people to purchase goods and services across international boundaries. Some companies rely heavenly on advertising against other promotional strategies to achieve this goal. In its February 2020 report, the Central Bank of Nigeria (CBN) put the total non-oil export earnings for Nigeria for the period under review at US\$143.84 million.

This figure indicated an increase of 9.3 percent relative to the level in the preceding month. The CBN equally noted that the figure was, however, 56.3 percent lower than the level that Nigeria achieved in the corresponding period of 2019. The development relative to the preceding period was due to an increase of 45.0 percent in food products, 26.1 percent in agricultural produce, and 15.2 percent in industrial sector receipts (Central Bank of Nigeria (2020).

Precisely, food products, agricultural and the industrial sectors earned US\$7.74 million, US\$77.58 million, and US\$31.24 million respectively. The shares of the various sectors in non-oil export proceeds were agricultural products, 53.9per cent; industrial sector, 21.7per cent; manufactured products, 18.1per cent; food products, 5.4per cent; and minerals, 0.9percent.

[C] Growth Agent For Gross National Product (GNP): Advertising has helped Nigeria to grow its Gross National Product (GNP). In 2011, Nigeria's advertising industry's spend on above-the-line advertising activities was N102.755 billion (Ekwujuru 2013, as cited in Abhay Chawla 2015). In 2018, advertising spends stood at N81.0 billion, though a reduction of 21.17 percent from the 2011 figure (Mediafactsbook 2018). Its quarterly analysis revealed that the first quarter recorded N20.4 billion, which indicated 25.2 percent, while the second quarter had N21.1 billion with 26 percent. The third quarter of N18.5 billion was 22.8 percent and the fourth quarter was N21.0 billion was 25.9 percent.

[D] Improvement Of The Standard Of Living: As an economic activity, it provides opportunities for people to improve their income. It motivates people to consume more material, thus improving their standard of living. As foreign advertisers use local media to promote their products and services, it runs off on local media organisations' revenues and, therefore, enhances the living standard of their staff. Equally, the consumers will receive a boost to their living standard, as multinational advertising will encourage the use of these varieties of products and services to improve their lives.

[E] Promotion Of Economic Growth: Advertising helps to contribute to the all-round development of the economies of countries. It does this through increasing demand and encouraging the economic activities of different countries. These activities stimulate people's desire to shop, which, in turn, supports the economies of different countries. Foreign advertising sellers like Google, Facebook, and Twitter attracted about \$86 million internet advertising in 2019 (Nairametrics 2019).

[F] Provision Of Employment: Effective advertising generates a strong desire for goods and services. High demand calls for more production, which requires more physical and human resources, thus creating employment opportunities. Aside from this, foreign advertising agencies will join their other counterparts to take advantage of the large population and huge investment opportunities.

For instance, Publicis Groupe, a leading global network of advertising agencies, and Troyka Group, Nigeria's largest marketing outfit, recently formalised a landmark equity acquisition relationship. Since the partnership, the two powerhouses have become a dominant machine in the advertising industry.

In Faleye (2017), Dr. Ken Onyeali Ikpe, while commenting on this, stated: "The partnership with Publicis is supposed to energize the system, create competence, elevate knowledge and skills sets in our group, and then we transfer that knowledge and skillset by way of providing solutions for our clients and that process are on. All members of the communication company have gone through training and immersion in the last two years and we have a change programme going on. Our Executive Creative Director of Insight has been posted to Publicis Africa as the Executive Creative Director and is working out of Accra in Ghana. We have many such cross-posting going on now."

[G] Reflection Of Cultural Trends: Advertising has helped to bridge the gap among people of different countries by communicating varied cultures through advertising messages. It has brought variation in social life. (Mooij 1998) has noted the fact that "consumer behaviour is culture-bound" and this is part of what multinational advertising is trying to exploit in promoting products and services across national boundaries.

\section{REFERENCES}

[1] Abhay Chawla 2015, Nigeria: Advertising the Economic Engine https://www.researchgate.net/publication/300583123

[2] Agbanu, V. N. \& Nwammuo, A. N (2009). Broadcast media: Writing, programming, management. Enugu: Rhyce Kerex Publishers.

[3] Asemah, E.S., 2012. Integrated marketing communication as a strategy for persuading consumers towards product purchase. Benin Mediacom Journal (5).

[4] Belch, G. E. and Belch, M. A. (2003). Advertising and Promotion: An Integrated Marketing Communication Perspectives. NY: The McGraw-Hill Companies

[5] Bovee, C.L and Arens, W.F (1992). Contemporary Advertising. New York McGrawHill Publishing Company

[6] Central Bank of Nigeria (2020), Economic Report February, 2020https://www.cbn.gov.ng/Out/2020/RSD/February\%202020\%20E conomic\%20Report.pdf

[7] Dominick, J. (2007). The dynamic of Mass Communication in the Digital Age. NY: McGraw-Hill Companies

[8] Ekwujuru, P. 2013. Advertising Spend Dipped by N11bn in 2012. In Vanguard Available at: http://www.vanguardngr.com/2013/09/ advertising-spend-dipped-by-n11bn-in-2012/. (Accessed on 20 June 2015.)

[9] Faleye, Tunji (2017), "Affiliation, Partnership and the Advertising Practice in Nigeria," Brand Communicator: 
https://brandcom.ng/2017/06/affiliation-partnership-advertising-practi ce-nigeria/

[10] Guttmann, A. (2019), Advertising revenue in Nigeria 2018-2020, https://www.statista.com/statistics/683543/nigeria-ad-spend-category/

[11] Lasune Suryakant, et al (2011), Sybcom-Advertising, Institute of Distance and Open Learning, University of Mumbai, Vidyanagari, Mumbai .

[12] Mediafactsbook (2018), https://www.mediafactsbook.com/nigeria/

[13] Mooij, Marieke De (1998): Global Marketing and Advertising. Understanding Cultural Paradoxes. Thousand Oaks, CA: Sage Publications Inc.

[14] Nairametrics (2019), Nigeria's Bluechips spend N114 billion on advertising, marketing in 2019 https://nairametrics.com/2019/12/03/nigerias-bluechips-spend-n114-bi llion-on-advertising-marketing-in-2019/

[15] Nwabueze, Chinenye; Ezebuenyi, Ephraim; Ezeoke, Chinwe, "Print Media Objectivity and Advertising Revenue: An Appraisal," African Research Review, An International Multidisciplinary Journal, Ethiopia: Vol. 6 (3), Serial No. 26, July, 2012: http://dx.doi.org/10.4314/afrrev.v6i3.23

[16] Sandage, C.H., Fryburger, V. and Rotzoll, K. 1989. Advertising: Theory and Practice (12th ed.) Longman Group United Kingdom

[17] Stanton William J. (1994), Fundamentals of Marketing, NY: McGraw-Hill Companies

[18] Svetlana Frolova (2014), The Role of Advertising in Promoting a Product, Theses on Degree Programme in Industrial Management, Centria University Of Applied Sciences 